\title{
Selection of Anti-Inflammatory Lactic Acid Bacteria From A Pool of Yoghurt Starter Cultures
}

\author{
Silvina del Carmen (I), Anderson Miyoshi (II), Vasco Azevedo (II), \\ Philippe Langella (III), Luis Bermudez-Humaran (III), Alejandra de \\ Moreno de LeBlanc (I), Jean Guy LeBlanc (I) \\ (I) CERELA-CONICET - Centro de Referencia para Lactobacilos (Chacabuco 145, San Miguel \\ de Tucuman, Argentina), (II) ICB-UFMG - ICB, UFMG (UFMG, Minas Gerais, Brazil), (III) INRA- \\ CRJ - INRA-CRJ (UMR1319 Micalis, Jouy-en-Josas, France)
}

\section{Resumo}

Inflammatory bowel diseases affect the quality of life of many people through the world. Previous studies demonstrated the anti-inflammatory potential of a yoghurt prepared with a pool of candidate probiotic strains of Lactobacillus (L.) delbrueckii subsp. bulgaricus and Streptococcus (S.) thermophilus from the CERELA Culture Collection. Considering that the probiotic effects are strain specific, the aim of this work was to select from this yoghurt, the LAB strains related to this anti-inflammatory effect and prove their potential in vitro and in vivo. M\&M: L. delbrueckii subsp. bulgaricus (CRL861, 863, 864, 866, 869, 871, 872 and 887) and S. thermophilus (CRL806 and 807) were grown separately to obtain the fermented milks (FM). The in vitro anti-inflammatory capacity of each FM was studied in co-culture with mononuclear cells isolated from Peyer's patches of healthy mice, by evaluating the cytokines IFNg and IL-10 in the supernatants. The in vitro selected FM were administered to healthy mice and to mice inoculated with TNBS (colitis model). Pro-inflammatory cytokines (IFNg, IL-17) and the regulatory cytokine IL-10 were evaluated in their intestines. Results: The in vitro studies demonstrated that the cocultures with FMs obtained with S. thermophilus CRL807 and L. bulgaricus 864 showed increased IL10/IFN $\gamma$ ratios. This IL10/IFN $\gamma$ ratio also increased in the intestinal fluids of healthy mice given these FMs. These mice also increased the ratio of IL10+ cells/IL17+ cells in their

\footnotetext{
Referência:

Silvina del Carmen, Anderson Miyoshi, Vasco Azevedo, Philippe Langella, Luis Bermudez-Humaran, Alejandra de Moreno de LeBlanc, Jean Guy LeBlanc.Selection of Anti-Inflammatory Lactic Acid Bacteria From A Pool of Yoghurt Starter Cultures. In: Anais do $1^{\circ}$ Congresso Latinoamericano de Microbiologia e Higiene de Alimentos MICROAL 2014 [= Blucher Food Science Proceedings, num.1, vol.1]. São Paulo: Editora Blucher, 2014. DOI 10.5151/foodsci-microal-219
} 
intestinal tissues. The anti-inflammatory potential observed in healthy mice was checked in the TNBS colitis induced model. Mice that received each FM or a yoghurt prepared with both strains, decreased the severity of the inflammation with less body weight loose, bacterial traslocation to liver and macroscopic and microscopic damages in the intestines. Mice that received FMs or yoghurt increased the ratio IL-10/IL-17 in the cells of the intestinal tissues. Conclusions: The anti-inflammatory capacity of milk fermented by L. bulgaricus CRL864, S. thermophilus CRL807 or a yoghurt prepared with both strains was demonstrated in vitro and in vivo. This potential was related to capacity to modulate the immune response in the intestine of the host in both healthy conditions and under an inflammation.

Palavras-Chave: ANTI-INFLAMMATORY, LACTIC ACID BACTERIA, YOGHURT

\section{Agência de Fomento:}

